\title{
Influence of Cooperative Members' Participation and Gender on Performance
}

\author{
Ching Choo Huang, Suhana Zazale, Rohana Othman, Nooraslinda \\ Abdul Aris and Siti Maznah Mohd Ariff
}

\author{
Accounting Research Institute and Faculty of Accountancy \\ Universiti Teknologi MARA, Shah Alam, Malaysia
}

Correspondence should be addressed to: Rohana Othman; rohana799@salam.uitm.edu.my

Received date: 11 October 2013; Accepted date: 18 February 2014; Published date: 10 April 2015

Copyright (C) 2015. Ching Choo Huang, Suhana Zazale, Rohana Othman, Nooraslinda Abdul Aris and Siti Maznah Mohd Ariff . Distributed under Creative Commons CC-BY 5.0

\begin{abstract}
Though its origin can be traced to the private sector, corporate governance is applicable to cooperatives which are a form of corporation. Thus, cooperatives too face issues associated with governance. Moreover, agency theory argues that the board of directors plays a crucial role in protecting shareholders' interests. Directors of cooperatives who act as agents to their members play a significant function linking managers' actions to the interests of their members and customers. Good and effective governance help to enhance the financial performance and sustainability of the cooperatives. The success of a cooperative depends on the degree of participation of its members. This paper aims to examine the association between cooperative governance in terms of members' participation and gender (male composition of the board), and cooperative performance. The study examined the annual reports from 2008 to 2012 of 34 cooperatives in Malaysia. It was found that male directors dominated the board of cooperatives in Malaysia. The relationship between male composition of the board and cooperative performance was insignificant. The mean of members' participation (attendance of directors at board meetings) was found to be high but it did not have any significant association with cooperative performance. The scope of analysis in this study was limited by the data set available. Further research on the influence of governance on cooperative performance can be explored in the future by looking at other governance characteristics via interviews or/and with the use of questionnaire survey.
\end{abstract}

Keyword: cooperative, governance, cooperative governance, performance

\section{Introduction}

Corporate governance is the process and structure used to direct and manage the business and affairs of a company towards enhancing business prosperity and corporate accountability with the ultimate objective of realising long term shareholder value, whilst taking into account the interests of other stakeholders (The Code, 2007). Though its origin can be traced to the private sector, corporate governance is applicable to cooperatives which are a form of corporation. Thus cooperatives too face issues associated with governance. Cooperative boards play a significant function in linking the managers' actions to the interests of their

Cite this Article as: Ching Choo Huang, Suhana Zazale, Rohana Othman, Nooraslinda Abdul Aris and Siti Maznah Mohd Ariff (2015)," Influence of Cooperative Members' Participation and Gender on Performance", Journal of Southeast Asian Research, Vol. 2015 (2015), Article ID 610199, 
members and customers. The boards are principally responsible for monitoring the performance of management, forming longterm strategic plans, evaluating proposals presented by management, and understanding the financial and strategic actions undertaken by the cooperatives (Bond, 2009). Good and effective governance help to enhance the financial performance and sustainability of the cooperatives.

Like the corporation, the directors act as the agent of the members in a cooperative which statutorily, is controlled by its members. The directors are to serve the interests of these members. The agency theory argues that in order to protect the shareholders' interest, the board of directors plays a vital role. A study by Osterberg and Nilsson (2009) involving over 2000 Swedish farmers revealed that the success of the cooperative depends on the degree of participation of its members. In general, good governance of cooperatives promotes discipline, transparency, independence, accountability, responsibility, fairness and social responsibility (Chibanda, Ortmann and Lyne, 2009).

This paper seeks to explore the association between cooperative governance and performance among cooperatives in Malaysia. The paper is structured as follows. The next section following the introduction reviews extant literature on the definitions of cooperatives, governance and the relationship between governance and cooperative performance. This is followed by research methodology and then findings and discussion. The paper concludes with some limitations encountered during the study and recommendations for future research.

\section{Literature Review}

\section{Cooperatives}

The International Cooperative Alliance (Cooperative Societies Act 1993, Section 2) has defined a cooperative as "an autonomous association of persons united voluntarily to meet their common economic, social and cultural needs and aspirations through a jointly owned and democratically controlled enterprise based on the cooperatives principles". The International Cooperative Alliance has adopted seven cooperatives' principles accepted by cooperatives around the world as foundational principles for establishing cooperatives. The cooperatives place these values into their cooperative practices. These seven cooperatives' principles are: (1) voluntary and open membership, (2) democratic member control, (3) members' economic participation, (4) autonomy and independence, (5) education, training and information, (6) cooperation among cooperatives and (7) concern for community.

The operations of cooperatives are based upon the value of self-help, selfresponsibility, democracy, equality and solidarity. In line with their founders, cooperative society members accept the ethical value of honesty, openness, social responsibility, and caring for others as claimed by the International Cooperative Alliance. Cooperatives have always been considered as an economic agency with a strong social responsibility towards the members in particular and the society at large.

\section{Cooperatives in Malaysia}

Cooperatives in Malaysia were first established in 1922, the year which the Cooperative Societies Enactment 1922 was enacted. The early objectives of cooperatives were to improve the standards of living in the rural areas and to eradicate poverty. Since then, the cooperative movement in Malaysia has impacted the economic development of the nation (Aini, Hafizah, and Zuraini, 2012). Cooperative members (also known as userowners) are responsible in running the cooperative businesses so as to improve the nation's socio economic well-being (National Cooperative Policy II (NCP II), 2011-2020). The increasing number of cooperatives in Malaysia serves as a good indication that people are more confident with cooperatives as a way to improve their living in the context of economic, 
political and environment (Yearly Financial Report of Cooperatives, 2010).

The National Cooperative Policy II (NCP II) 2011-2020 was launched by the prime minister of Malaysia on 16 July 2010. This marked a significant recognition of the contribution of cooperatives to the Malaysian economy. The formulation of both the NCP I (2002-2010) and NCP II (2011-2020) are to provide guidance for cooperatives to improve their performance, thereby helping to contribute to the economic growth and national development (Yearly Financial Report of Cooperatives, 2010). Moreover, this policy has been developed on the concept of One (1) Malaysia: People First, Performance Now. The cooperative sector in Malaysia was targeted as the third engine of the nation's economic development in the Ninth Malaysian plan, and is expected to increase its contribution to $5 \%$ of the Malaysian Gross Domestic Product in 2013 as reported by the Yearly Financial Report of Cooperatives (2010).

With such apparent development, there is a need for cooperatives to step up their performance in order to achieve the national vision as a driver of the cooperative excellence to contribute towards national development. This paper explores the performance of Malaysian cooperatives in the context of governance particularly members' participation and male composition on the board of directors on performance.

\section{Governance in Private Sector and Cooperatives}

Corporate governance is defined as "the relationship between shareholders, creditors, and corporations; between financial markets, institutions and corporations, and between employees and corporations. Corporate governance would also encompass the issue of corporate social responsibility, including aspects such as the dealings of the firm with respect to culture and the environment" (Claessens, 2003, p5). Various benefits such as better firm performance, better access to external finance and lower costs of capital can be linked to more effective corporate governance standards. Good governance such as transparency, accountability, risk management and control enhances the overall performance of businesses in the private sector.

The structure or composition of the board has an influence on the effectiveness of the board. The Code of Best Practices provides guidelines for the proper functioning of cooperatives in Malaysia. Good cooperative governance is built upon the relationships between the members of cooperatives, the Board of Directors and the management. The members of the cooperatives elect the board of directors who set policies and plan strategically for the success of the cooperatives. The board may also hire managers to assist them in carrying out their duties. The success of the cooperatives can be measured by its financial performance and also its ability to fulfill other non-financial objectives including meeting the social needs of their members.

\section{Governance and Performance}

All organizations, including cooperatives or charitable organizations and public sector, need to measure their performance regardless whether they are profit oriented. Past studies have revealed that performance measurement provided more informed decisions for the future strategies of organizations. It assists organizations in strategic planning, management and continuous improvement. In order for cooperatives to contribute to the socio economic development of Malaysia, some form of performance measurement is therefore essential (Aini, Hafizah, and Zuraini, 2012).

Attempts have been made to assess cooperative performance, but there is no one best way to evaluate such performance (Epstein, 2002). Despite that, measuring performance is vital for cooperatives. Financial ratios are commonly used by cooperatives to evaluate their performance as they are easily understood and can be calculated using the financial data provided by the financial statements. Traditionally, 
the financial measures such as profitability, liquidity and efficiency were used to assess the performance of a cooperative.

\section{Members' Participation}

Members' participation is an important issue to be considered in the cooperative sector (Birchall and Simmons, 2004a). A strong membership base is the foundation for the success of a cooperative. Harun et al. (2012) supported this by stating that the new perspective of cooperative movement in strong membership contributes to the growth of cooperative performance. The presence of group cohesiveness determines the success of cooperatives and should help in the economic development of Malaysia. A higher degree of the group cohesiveness contributes to higher organizational performance of the cooperatives. Hence, more cooperatives take extra efforts to build a strong membership such as getting their members to participate in the activities of the cooperatives. Aini et al. (2012) found that participation from members is vital for the growth of cooperatives in Malaysia. Even though members may not be actively involved in the administration of cooperatives, their opinions at the annual meeting are essential.

Osterberg and Nilsson (2009) found that there are considerable differences in members' commitment and trust in farming. This is due to their satisfaction with the profitability of the farm operations, their age, and their experience from board work. Besides, the study also revealed that the members' perception of participation in the democratic control of cooperatives outweighs all other factors. Participatory democracy is related to cooperative principles and the board can count on the support of the members in their decision, as long as the members are satisfied that they have a good chance to exercise democratic control (Osterberg and Nilsson, 2009).

Othman et al. (2012) found that the success of the cooperatives not only rely on the efficiency and effectiveness of the governance and management, but also on the members' participation. This is because members play a key role in the failure or success of the cooperatives since members are those who contributed financially and supported the activities of the cooperatives. The study of Othman et al. (2012) also revealed that members who attended the annual general meetings are one to three times more likely to contribute to the cooperatives' share increment as compared to those who were absent from these meetings. The share increment had a positive association with the annual general meeting attendance as their attendance promotes group cohesiveness and encourages members to achieve cooperative objectives.

Chibanda, Ortmann and Lyne (2009) evaluated the impact of institutional and governance factors on the performance of 10 smallholders agricultural cooperatives in KwaZulu-Natal (KZN). They conducted a cluster analysis of variables measuring three constructs, namely performance, institutional and governance indicators. It was found that the performance of 10 of these cooperatives was influenced by the institutional and governance problems. The governance problems are strongly linked with the ballot system (absence of secret ballot), low levels of education, lack of production and management skills training, weak marketing arrangements and consequent low returns to members as patrons or investors.

Furthermore, a study on 322 farmermembers of French agricultural cooperatives from the cereal-supply sector found that members' affective commitment is a mediator in the relationship between the affective and cognitive trust granted to the cooperative and members' participation in its governance (BarraudDidiera, Henninger and Akremic, 2012). Their study showed that members' trust impacted their participation through their affective commitment and the mediator effect of affective commitment between trust and participation was complete. According to Birchall and Simmons (2004b), the size of the cooperative group need not be considered as a major hurdle, 
provided the commitment to the members is strong.

In a different study, Amini and Ramezani (2008) found that members' participation in cooperative administration at a medium level did have an effect on the success of cooperatives. Besides, this study also found that members' participation depends upon the age and education of the members, their level of investments, the usefulness of the cooperative to members and their technical skills. Other researchers like Zheng et. al. (2012) found that farmers' participation behavior is closely related to their perceptions of professional cooperatives, and that educational attainment influences the farmers' perception level.

\section{Gender}

Zhao et al. (2013) identified the major roles played by women and their contributions to various sectors such as fishing, families and communities, trading, processing and management of the private sector. Their study revealed that women are often under-represented, unrecognized, unpaid or underpaid and they seemed to have little say in making business decisions in the fishing industry. The study identified that the main barrier for women to participate in the fishing industry is the working environment like the hours of work and hygiene factors which are non-conducive for women. In the study by Muroki et al. (1997), it was found that women's involvement in nutribusiness strategy helps them to acquire knowledge and skills which enable them to generate income for themselves and for their households.

\section{Research Methodology}

Sample

A sample comprising 39 cooperatives was selected for this study. Their annual reports were obtained from the library of the Cooperatives College of Malaysia.

\section{Variables and Their Measurements}

In this study, gender is represented by the male composition on the board of directors which was calculated by taking the number of male directors divided by the total directors sitting on the board. Members' participation is represented by the attendance measured in terms of percentage. As the data on members' attendance at the annual general meeting were not readily available, this study opted to use the percentage of attendance based on the number of meetings multiplied by the board size minus the number of absentees divided by the product of the number of meeting and board size. The proxies used for the performance of cooperatives are: return on assets (ROA) and return on equity (ROE). Return on assets was computed by dividing the profit before interest and tax by total assets less current liabilities. Return on equity was calculated by dividing the profit before interest and tax by equity. The data on male composition on the board of directors, attendance, financial data for the calculation of the financial ratios, namely ROA and ROE were collected from the annual reports.

\section{Findings and Discussion}

\section{Sample}

From the 39 cooperatives sampled in the study, only 34 cooperatives have published financial statements while the remaining five did not present any financial statements in the annual reports. Table 1 reveals that out of the 34 cooperatives, eighteen (53\%) are listed in the top 100 cooperatives in 2012. Forty seven percent of the sample is non-top 100 cooperatives. 
Table 1: Sample: Top and Non-Top 100 Cooperatives

\begin{tabular}{|c|c|c|c|}
\hline Cooperative & Top 100 & Non-Top 100 & Total \\
\hline Number & 18 & 16 & 34 \\
\hline Percentage & $53 \%$ & $47 \%$ & $100 \%$ \\
\hline
\end{tabular}

Data were obtained from the annual reports from 2008 to 2012 of these companies. Table 2 reveals that 12 annual reports $(35 \%)$ employed were for the financial year ended in 2012, and 11 (32\%) were for the financial year ended in 2011. The remaining 11 annual reports came from 2008, 2009 and 2010.

Table 2: Financial Year of Annual Reports

\begin{tabular}{|l|l|l|}
\hline Financial Year & Number & Percentage \\
\hline 2008 & 4 & $12 \%$ \\
\hline 2009 & 3 & $9 \%$ \\
\hline 2010 & 4 & $12 \%$ \\
\hline 2011 & 11 & $32 \%$ \\
\hline 2012 & 12 & $35 \%$ \\
\hline Total & $\mathbf{3 4}$ & $\mathbf{1 0 0} \%$ \\
\hline
\end{tabular}

\section{Descriptive Statistics}

The results of descriptive statistics on male composition, attendance, return on assets and return on equity are displayed in Table 3.

Table 3: Descriptive Statistics

\begin{tabular}{|l|c|c|c|c|c|}
\hline Variables & Number & Minimum & Maximum & Mean & $\begin{array}{l}\text { Standard } \\
\text { Deviation }\end{array}$ \\
\hline Male composition & 34 & 70.00 & 100.00 & 93.5000 & 7.8480 \\
\hline Attendance & 23 & 88.00 & 100.00 & 95.7826 & 4.0109 \\
\hline ROA & 34 & -0.28 & 4.88 & 0.2135 & 0.8309 \\
\hline ROE & 34 & -1.16 & 1.00 & 0.3282 & 0.3868 \\
\hline
\end{tabular}

The mean of male composition is $93.50 \%$, its maximum is $100 \%$, and its minimum is $70 \%$. Table 4 further reveals that 17 cooperatives (50\%) have all male directors, and seven cooperatives (21\%) have greater than $90 \%$ but less than $100 \%$ of their boards comprised of male directors.
Clearly, the composition of the boards among Malaysian cooperatives is highly dominated by males. This is consistent with that found by Zhao et al. (2013), even though their study focused more on the private sector. 
Table 4: Male Composition of the Board

\begin{tabular}{|c|c|c|}
\hline $\begin{array}{c}\text { Male } \\
\text { Composition }\end{array}$ & $\begin{array}{c}\text { Number of } \\
\text { cooperatives }\end{array}$ & Percentage \\
\hline $100 \%$ & 17 & $50 \%$ \\
\hline $90 \%-100 \%$ & 7 & $21 \%$ \\
\hline $80 \%-90 \%$ & 9 & $26 \%$ \\
\hline $70 \%-80 \%$ & 1 & $3 \%$ \\
\hline$<70 \%$ & 0 & $0 \%$ \\
\hline Total & 34 & $100 \%$ \\
\hline
\end{tabular}

As for the attendance, its mean is about $96 \%$ with a minimum of $88 \%$ and a maximum of $100 \%$ (see Table 3). The means of return on asset and return on equity are 0.2135 and 0.3282 , respectively.

\section{Correlation Analysis}

Pearson correlation analysis was conducted on the data collected. The analysis was on the association between attendance and male composition of the board with performance (measured in terms of return on assets and return on equity). The results of Pearson correlation are shown in Table 5. All the relationships were found to be insignificant except for male composition and attendance. This indicates that the higher the male composition the lower the attendance of board meetings.

Table 5: Pearson Correlations

\begin{tabular}{|l|c|c|c|c|}
\hline Variables & $\begin{array}{c}\text { Male } \\
\text { Composition }\end{array}$ & Attendance & ROA & ROE \\
\hline $\begin{array}{l}\text { Male } \\
\text { Composition }\end{array}$ & 1 & & & \\
\hline Attendance & $-0.432^{*}$ & 1 & & \\
\hline ROA & -0.018 & -0.036 & 1 & 1 \\
\hline ROE & -0036 & 0.227 & 0.024 & \\
\hline
\end{tabular}

Note: * Correlation is significant at the 0.05 level (two-tailed)

Table 5 shows that there is positive association between attendance and return on equity indicating the higher the attendance the higher is return on equity, but the relationship is not significant. This result contradicts that of Amini and Ramezani (2008) who found that members' participation in cooperative administration even at a medium level did have an effect on cooperatives' success.

\section{Conclusion and Recommendation}

In summary, male directors were found to dominate the board of cooperatives in Malaysia. Results obtained from this study did not show any significant relationships between the male composition on the board and directors' participation with performance, thus dispelling previous notions expounded in the literature claiming members' participation had a relationship with cooperative performance. A possible reason for this observation is this study had used 'attendance of 
directors' as proxy for members' participation unlike other studies. In addition, the proxy used for performance in this study is solely financial ratios. Since performance of cooperatives can be nonfinancial, the results did not find any significant associations between male composition and directors' participation and performance.

The limited data available in the annual reports are the major setback of the study.

\section{References}

1. Aini, Y. M., Hafizah, H. A. K., and Zuraini, Y. (2012), 'Factors Affecting Cooperatives' Performance in Relation to Strategic Planning and Members' Participation,' Procedia-Social and Behavioral Sciences, 65, 100-105.

2. Amini, A. M., and Ramezani, M. (2008), 'Investigating the Success Factors of Poultry Growers' Cooperatives in Iran's Western Provinces,' World Applied Sci. J, 5, 81-87

3. Barraud-Didiera, V., Henninger, M-C and Akremic, A.E. (2012), 'The Relationship between Members' Trust and Participation in the Governance of Cooperatives: The Role of Organizational Commitment,' International Food and Agribusiness Management Review, 15(1), 1-24.

4. Birchall, J., and Simmons, R. (2004a), 'What Motivates Members to Participate in Cooperatives and Mutual Businesses?' Annals of Public and Cooperative Economics, 75(3), 465-495.

5. Birchall, J., and Simmons, R. (2004b), 'The Involvement of Members in the Governance of Large-scale Co-operative and Mutual Businesses: A Formative Evaluation of the Co-operative Group,' Review of Social Economy, 62(4), 487-515.

6. Bond, J. K. (2009), 'Cooperative Financial Performance and Board of Director Characteristics: A quantitative investigation,' Journal of Cooperatives, 22, 22-44.
This can be overcome by cooperative visits to obtain the missing data directly from the cooperatives. The sample size can be increased for future studies. Further research with the use of a questionnaire would help to further explore the relationship between members' participation and cooperative performance. Other characteristics of governance such as board size can also be examined via interviews in the future.

7. Brasilia (2008), "The cooperatives governance: and mutual associations: Guideline for good practices of financial cooperative governance," [Retrieved October 2, 2013],

8. http://www.bcb.gov.br/pre/microFina ncas/coopcar/pdf/cooperative_governance _internet.pdf

9. Chibanda, M., Ortmann, G. F., and Lyne, M. C. (2009), 'Institutional and Governance Factors Influencing the Performance of Selected Smallholder Agricultural Cooperatives in KwaZulu-Natal,' Agrekon, 48(3), 293-315.

10.Claessens, S. (2003), “Corporate governance and development global corporate governance forum focus 1," Washington World Bank. [Retrieved October 3, 2013], http://www.gcgf.org/wps/wcm/connect/7 fc17c0048a7e6dda8b7ef6060ad5911/Foc us_1_Corp_Governance_and_Development.p df?MOD=AJPERES

11.Epstein, M. J. (2002), Measuring and Managing Performance in the 21st Century, 1-14, The Performance Prism: The scorecard for measuring and managing business success, Neely A., Adams C. and Kennerley M. (ed) Prentice Hall, UK.

12.Harun, M. Z. M. B., and Mahmood, R. B. (2012), 'The Relationship between Group Cohesiveness and Performance: An Empirical Study of Cooperatives Movement in Malaysia,' International Journal of Cooperative Studies, 1(1), 15-20.

13.International Co-operative Alliance (ICA) (2013), Official website of the International Co-operative Alliance. (n.d.). ICA: International Co-operative Alliance. 
[Retrieved October 5, 2013], http://ica.coop/

14.Muroki, N. M., Maritim, G. K., Karuri, E. G., Tolong, H. K., Imungi, J. K., Kogi-Makau, W., and Maretzki, A. N. (1997), 'Involving Rural Kenyan Women in the Development of Nutritionally Improved Weaning Foods: Nutribusiness Strategy,' Journal of Nutrition Education, 29(6), 335-342.

15.Official Portal Ministry of Domestic Trade, Co-Operatives and Consumerism . (n.d.). (2013), Portal Rasmi Kementerian Perdagangan Dalam Negeri, Koperasi dan Kepenggunaan. [Retrieved October 6, 2013], http://www.kpdnkk.gov.my/en/kpdnkk/d asar/dasar-koperasi-negara

16.Official Portal Suruhanjaya Koperasi Malaysia. (n.d.). (2013), Portal Rasmi Suruhanjaya Koperasi Malaysia. [Retrieved October 6, 2013], http://www.skm.gov.my/en/laporantahunan

17.Osterberg, P., and Nilsson, J. (2009), 'Members' Perception of Their Participation in the Governance of
Cooperatives: The Key to Trust and Commitment in Agricultural Cooperatives', Agribusiness, 25(2), 181-197.

18.Othman, A., Kari, F., Jani, R., and Hamdan, R. (2012), 'Factors Influencing Cooperative Membership and Share Increment: An Application of the Logistic Regression Analysis in the Malaysian Cooperatives,' World Review of Business Research, 2(5), 24-35.

19.The Code (2007), The Malaysian Code on Corporate Governance. [Retrieved October 6, 2013], from http://www.micg.net/brochure

20.Zhao, M., Tyzack, M., Anderson, R., and Onoakpovike, E. (2013), 'Women as Visible and Invisible Workers in Fisheries: A case study of Northern England,' Marine Policy,37, 69-76.

21.Zheng, S., Wang, Z.and Awokuse, T. O. (2012), 'Determinants of Producers' Participation in Agricultural Cooperatives: Evidence from Northern China,' Applied Economic Perspectives and Policy, 34(1), 167-186. 